\title{
States and Social Movements in the Modern World-System ${ }^{1}$
}

\author{
Mangala Subramaniam \\ Purdue University \\ mangala@purdue.edu
}

The mark of the modern world is the imagination of its profiteers and the counterassertiveness of the oppressed. Exploitation and the refusal to accept exploitation as either inevitable or just constitute the continuing antinomy of the modern era, joined together in a dialectic which has far from reached its climax in the twentieth century. (Wallerstein 1976: 233)

Protest, struggle, and the urge for equality are as old as constricting structures such as caste hierarchy, inequality of power, wealth, and knowledge. Social movement theorists argue that movements, protests, and struggles are legitimate expressions of popular interests and attempt to explain why, when, and how people protest and make claims. Protests and challenges to inequalities have been visible in discourse and movement activities all over the world. Efforts to challenge structural inequities also reveal the complex locations of different groups, particularly in the context of the current trends in globalization. While some attempts have been made to expand the contemporary social movement scholarship in the United States to include international cases, the field remains fragmented. At the same time, an increasing number of U.S.-based scholars are now interested in movement dynamics across countries and contexts.

A significant set of movements globally and across countries have and continue to challenge the consequences of globalization and specifically the neoliberal agenda. Neoliberalism generally refers to the ideology that advocates the dominance of a competitiondriven market model and includes a set of policy prescriptions that have defined the world economy since the late $1970 \mathrm{~s}$. Within this doctrine, individuals in a society are viewed, if viewed at all, as autonomous, rational producers and consumers whose decisions are motivated primarily by economic or material concerns. But this ideology has little to say about the social and economic inequalities that distort real economies. The neoliberal order that is supported by powerful states and wealthy corporate interests has been expanding over time, but that order is also being vigorously challenged by movements acting both locally and transnationally.

Scholars have begun to integrate tenets from the world-systems approach with perspectives in social movements to develop an understanding of the dynamics of movement action as occurring within a world-systemic context (cf. Smith and Wiest 2012; Kaup 2013). How have changes such as globalization trends and the adoption of neoliberal policy agendas affected the livelihood of people? How have people across rural and urban spaces and across

\footnotetext{
${ }^{1}$ I appreciate very much the comments and suggestions from Jackie Smith on the draft of this article. I thank Suresh Garimella, the then Associate Vice President for Engagement, and his office at Purdue for the grant that made the symposium in Chennai possible. I am also grateful to K. Kalpana, R. Santhosh, and Binitha Thampi and the Department of Humanities and Social Sciences at IIT, Madras for collaborating to organize the symposium on IITMadras campus.
}

This work is licensed under a Creative Commons Attribution 4.0 United States License. Journal of World-Systems Research, Volume 21, Number 1, Pages 1-7, ISSN 1076-156X 
countries assessed opportunities and threats and built movements to resist the capitalist worldsystem? These are the broad questions addressed in this special issue.

This special issue draws from papers presented at a symposium on the state and social movements, organized jointly by Purdue University's department of sociology and the Indian Institute of Technology (IIT), Madras's Humanities and Social Sciences Department and convened at the IIT campus in March 2013. The articles interrogate the power of the state and state institutions within a broader world-system and explore the implications for social movement challenges to this power.

Throughout the history of modern democracy, contradictory claims and policies have served as a basis for social movement action, which is often about resisting market forces and demanding rights. Nonetheless, these papers cover several issues related to challenges to neoliberalism and the state in the world-system: environmental justice, state engagement in resistances to neoliberalism and the world capitalist system, the roles of micro-enterprise development (self-help groups), and the character of mobilization dynamics and leadership of organized challenges in the context of neoliberal agrarian policies such as opposition to GM (genetically modified) crops.

Along with an emphasis on the transnational nature of movements, the articles in this special issue focus on the global South. In sum, authors examine how global forces impact social movement politics, the local character of neoliberalism and resistance, and the tendency of states to support (or not) counter hegemonic struggles. Our consideration of cases in this issue is based on movement politics as being complex, comprising multiple actors and economic and social forces that include the state, NGOs, and global institutions. Moreover, state structures themselves vary, and this variation can impact social movement mobilization. The cases that follow are based in places and countries that have increasingly been integrated into the world system and that continue to see intense struggles against the growing capitalist economy. Considering the translocal character of neoliberalism, struggles in both core and periphery nations may involve the targeting of the state, corporations, and other global economic institutions. Below I discuss the three main ways the papers in this issue contribute to the effort to better integrate worldsystems tenets with conceptualizations in social movement theory.

\section{Role of State}

First, the articles utilize Sklair's (1999) argument to consider "processes that transcend the nation-state" and thus to look beyond the state as the unit of analysis. But the state is not a monolithic whole, nor is its structure stable and constant. The nature of state boundaries and authority is changing as a result of changing patterns of relations among states, including evolving international norms (Appadurai 1996; Ohmae 1990 1995; Strange 1996). Moreover, the state itself may adopt an anti-neoliberal stance, which Almeida, in this issue, describes as antineoliberal political parties (more below).

World-systems scholars draw our attention to the ways in which neoliberal globalization transforms the state. They include advocating and enforcing deregulation, reduction in state spending (particularly in the social sector), and increased foreign investment and trade (Harvey 2005; Robinson 2004). Adoption of these policies has reduced states' roles in providing basic services such as education and health while enhancing the power of private sector actors. Thus the neoliberalization of the state has been particularly detrimental to the countries of the global 
South and to people with relatively less access to resources. However, people in the global South (and global North) have not idly watched their lives being transformed in the name of development; they have organized and resisted this collectively (cf. Subramaniam 2014; Sassen 2013; Smith and Wiest 2012; Almieda and Johnston 2006, among others).

As Angelique Haugerud observes, "Neoliberalism has sparked a stunning array of popular countermovements" (2010:112) that often target corporate and state power. Since the late $1990 \mathrm{~s}$, there has been a growing tendency to understand these kinds of movement politics as responding to various forms of "dispossession" unleashed as part of the latest wave of neoliberal globalization. Such endeavors for profit accumulation are closely linked to the global capitalist system, but the struggles against accumulation by dispossession are of greater importance in the global South (Harvey 2003). Both Almeida and Kalpana, in this issue, discuss the role of the state in these contests.

Women organized in self-help groups are disciplined by the state to contribute to the capitalist agenda (Kalpana). But this has enabled women to emerge as agents to seek change beyond the financial benefit. The local character of neoliberalism is visible in household-based initiatives such as micro-enterprise development and self-help groups, a theme explored by Kalpana in this special issue. While world-systems analysts examine such household-based subsistence work as key to the maintenance of the capitalist world-system, feminists who work within the world-system approach highlight the economic contributions of women. But as argued by Wallerstein and Smith (1984), informal sector activity is a market transaction which depends on the ability of the state to alleviate the inequalities that arise from promoting capitalism. Drawing from the world-systems approach, Karides (2010), explains the expansion of microenterprise development under neo-liberalism as reflective of two separate "strategies of dealing with economic crises - informal or unwaged work and government transfer or social safety nets-merged into one" (p. 192). This expansion has been made possible by the state and has focused largely on women. Feminists have expressly elaborated the economic contributions that women made to households through their informal enterprises.

Turning to the changing stance of the state, it is pertinent to note that especially in Central America, the alliance between emerging anti-neoliberal political parties and popular movements. These trends challenge the world capitalist society. The decades of implementation of neoliberal policies in Central America have been resisted by social movements and a new path to progress is being ushered in (Almeida and Johnston 2006). In his analysis of all six Central American States, Almeida concludes that the "shift from state-led development to neoliberal forms of capitalism at the global level provided new threats and incentives for antisystemic forces to form electoral political parties as a strategy to resist new harms associated with the loss of citizenship rights" (p. 19).

\section{Resistances to Local and Translocal Neoliberalism}

Second, and related to the first point above, several of these essays provide a critical, and much needed perspective on the local face and character of the consequences of neoliberalism and resistances by movements particularly in semi-peripheral countries. While neoliberalism itself is translocal in nature, movement dynamics, including their trajectory, can play out differently in different places (Subramaniam 2014). Contributing to the discussion of neliberalism, critical geographers assert that there is "neoliberalization" of socio-nature-a term that is used to 
highlight the particular ways in which specific "local neoliberalisms" are embedded in broader structures and relations of neoliberalism, which is heterogeneous and contested (Bakker 2005: 544; Peck 2001; Peck and Tickell 2002). As noted by Kaup (2013), the struggles against exploitation and accumulation at the local level are tied to global economic change.

Specific "local neoliberalisms" are located within broader structures and relations of neoliberalism, which is a heterogeneous and contested. In fact, global engagements in advocacy and protest is "influenced by processes of mobilization in particular national contexts" (Scoones 2008: 159). Yet these processes are transnationally linked. In the loose network making up global protestors, the GM issue has become a focus of interlinked protests against the "monopolization of knowledge and technology ownerships through patents and the TRIPS agreement, for trade justice as part of the reform of the WTO, against the perceived depredations of multinationals (such as Monsanto), or in relation to wider rights campaigns around food, health and farming" (Scoones 2008: 157). Struggles against exploitation and dispossession do not merely converge when facing a common oppressor, but also when the changing forms and geographies of exploitation and dispossession bring people together in common places (Kaup 2013). This is particularly evident in the discourse around GM (genetically modified) crops in India. For many involved in the politics of biotechnology, the national frame was about broader issues of rights and social justice in the context of neoliberal agrarian policies (see Roy in this issue).

World-systems analysts have understood social movements as challenging and resisting the underlying structures of the world economy. But they also recognize that not all movements challenge the system or view the issues they contend with as being inter-connected (Hall and Fenelon 2009). Some of these challenges have a local character and are often loosely linked. Such struggles shape and transform opportunities by advancing claims and challenging power within countries and can at the same time contribute to the broader anti-system movements. In addition, new movements may emerge to find ways of meeting the basic needs of those made vulnerable by the state's withdrawal. At the same time, the movements that emerge at a local or national level may fail or demobilize. Therefore, our analyses must trace the trajectory of these movements and identify the productive outcomes that may emerge.

According to world-systems analysts, the world economy is not composed of individual national economies interacting independently of one another, but tied together by a complex network of capitalist relations. The relations among core, periphery, and semi-periphery countries are historically conditioned and shaped by an integrated single capitalist world-system. Periphery countries are subject to the core's development and expansionist policies and practices because they lack an internal dynamic that would allow for acting as an independent and autonomous entity within the world world-system (McMichael 2012). Specifically, they are subject to the rules of the hegemonic regime - shaped by the dominant players in the worldsystem (Arrighi, Giovanni 1994; Arrighi and Silver 2001; Arrighi, Silver, and Brewer 2003).

Core countries retain power through the domination of economic, political, and cultural life on a world scale. Peripheral and semi-peripheral countries are subject to what Emmanuel (1972) terms unequal exchange through trade; meaning that core countries define terms of international trade which are disadvantageous to less developed countries. In the context of contemporary neoliberal globalization, unequal exchange is no longer propagated by core states alone but also by transnational corporations which seek to maximize accumulation through the creation of a system of dependency and exploitation (Bradshaw and Wallace 1996). 
As Wallerstein (2004: 26) comments, states can create quasi-monopolies through patents, and other protectionist measures. Quasi-monopolies depend on the patronage of strong states, and so the firms creating quasi-monopolies are largely located within strong states. Strong states can use their muscle power to prevent weaker states from creating counter-protectionist measures. Roy in her analysis of the anti-GM movement notes that the medium-strong semiperipheral Indian state is not in a position to either prevent the strong hegemonic core state and its leading firms from selling their transgenic technologies to Indian firms or to prevent the flow of technology fees from Indian farmers to the core bourgeoisie, especially after the Indian state approved the commercialization of a particular kind of GM seed. The anti-GM coalition has been successful in pressing ideologically different political parties to protest against the multinational seed firms based in core states. Further, it has enabled the Indian state to move from a subimperialist to an anti-imperialist role regarding GM seeds. However, Roy asserts that "until the anti-GM coalition in India resolves its inner contradictions and becomes resolutely anti-capitalist and anti-systemic, it will not be able to effectively challenge the anti-imperialist Indian state's pro-capitalist stance regarding GM seeds and industrial agriculture" (p. 88).

In a similar vein and using a comparative case approach, Frey discusses the particular form of core-periphery reproduction or core capital accumulation as related to ship breaking. The process of ship breaking contributes to adverse health, safety, environmental, and socioeconomic consequences in the periphery and semi-periphery locales of nations in the world system but is explained as being beneficial to the core and the states concerned, domestic firms, workers, and citizens. As very few semi-peripheral countries have the capacity or ability to address the risks associated with hazards such as ship breaking, the adverse consequences for its people has spawned resistance. Frey's article draws attention to the exploitation of environmental space by the advanced capitalist countries (the core).

\section{Dynamics of Mobilization}

Third, the articles examine the dynamics of mobilization processes as influenced by the variable opportunities of neoliberalism. Two articles in this special issue (Lapegna, Roy) consider mobilization dynamics in the agrarian sector. The agrarian sector, in a manner has witnessed intense farmers' struggles. Local farmers' movements are embedded in broader structures and relations of neoliberalism. In fact, the local face of neoliberalism combined with the privatization agenda of the state has shaken rural society in particular (Borras et al 2008). In their analysis of transnational agrarian movements (TAM), Borras et al (2008) emphasize that "class too must be considered in any analysis of movement-building and agrarian change dynamics" (p. 25). Class analysis is also important for the analysis of the dissipation of farmers' movements.

Focusing on a variant of dissipation of movement by examining the case of genetically modified soybeans, Lapegna draws attention to the aspect of class as he examines the demobilization of popular movements and the mobilization of agribusiness. The introduction of GM soybeans in Argentina has been advanced the interests of agribusiness companies and large farmers but resulted in adverse life circumstances for peasants and indigenous peoples, who faced land evictions and health problems from agrochemical exposure. Using primary qualitative data and integrating food regime scholarship and world-systems perspective, Lapegna unravels the relationship between the state and neoliberalism related to agricultural technology which 
shows the role of privileged sectors, such as agribusinesses, in promoting a neoliberal agenda. Roy also examines mobilization against GM seeds in India.

In her analysis, Roy describes the role of the state in seeking public opinion and thereby facilitating mobilization against GM seeds as was evident from the massive outpouring of letters and other documents from scientists, agriculture experts, farmers' organizations, NGOs, consumer groups and people from all walks of life. In India, a mélange of actors - drawn from the fields of government, judiciary, parliament, civil society, media and businesses, among others-have jousted with each other for at least two decades regarding the introduction of biotech, transgenic or genetically engineered, crops in India. While the initial focus in the 1990s was on the introduction of Bt cotton, which was commercialized in 2002 by the Indian government, the attention has now shifted to another transgenic crop, Bt brinjal. There is no national-level consensus emerging on whether Bt brinjal should be commercialized or not. Much of this indecision is due to the work of the anti-biotech domestic activists.

Although the emphasis of the March 2013 symposium was India, this special issue of the Journal of World-Systems Research recognizes the importance of extending our attention beyond India. Included in this special issue are cases from Argentina and Bangladesh in a comparative paper which illustrates the central themes analyzed in this special issue. I also expect scholars working in other regions of the world to apply the framework and findings from the papers in this collection to examine cases in other countries.

\section{References}

Almeida, Paul and Hank Johnston. 2006. "Neoliberal Globalization and Popular Movements in Latin America." Pp. 3-18 in Latin American Social Movements: Globalization, Democratization, and Transnational Networks edited by Paul Almieda and Hank Johnston. Lanham, MD: Rowman and Littlefield.

Appadurai, Arjun. 1996. Modernity at Large: Cultural Dimensions of Globalization. Minneapolis, MN: University of Minnesota Press.

Arrighi, Giovanni. 1994 (2010). The Long Twentieth Century: Money, Power and the Origins of our Times. New York: Verso.

Arrighi, Giovanni and Beverly J. Silver. 2001. "Capitalism and World (Dis)Order." Review of International Studies 27.

Arrighi, Giovanni, Beverly J. Silver, and Benjamin D. Brewer. 2003. "Industrial Convergence, Globalization, and the Persistence of the North-South Divide." Studies in Comparative International Development 38:3-31.

Bakker, Karen. 2005. "Neoliberalizing Nature? Market Environmentalism in Water Supply in England and Wales." Annals of the Association of American Geographers 95(3): 542-65.

Borras, Sauenino M., Marc Edelman, and Cristóbal Kay. 2008. "Transnational Agrarian Movements: Origins and Politics, Campaigns, and Impact." Pp. 1-36 in Transnational agrarian Movements: Confronting Globalization edited by Sauenino M. Borras Jr, Marc Edelman, and Cristóbal Kay. Oxford: Blackwell Publishing.

Dicken, Peter. 2011. Global Shift: Mapping the Changing Contours of the World Economy. $6^{\text {th }}$ ed. New York City: Guilford Press.

Emmanuel, Arghiri. 1972. Unequal Exchange. New York: Monthly Review. 
Hall, Thomas D. and James V. Fenelon. 2012. Indigenous Peoples and Globalization: Resistance and Revitalization. Boulder, CO. Paradigm Publishers.

Harvey D. 2003. The New Imperialism. Oxford: Oxford University Press. . 2005. The New Imperialism. Oxford, New York: Oxford University Press.

Haugerud, Angelique. 2010. Neoliberalism, Satirical Protest, and the 2004 U.S. Presidential Campaign. Pp. 112-127 in Ethnographies of Neoliberalism edited by Carol Greenhouse. Philadelphia: University of Pennsylvania Press.

Karides, Marina. 2010. "Theorizing the Rise of Microenterprise Development in Caribbean Context." Journal of World Systems Research XVI (2): 192-216.

Kaup, Brent Z. 2013. "In Spaces of Marginalization: Dispossession, Incorporation, and Resistance in Bolivia." Journal of World Systems Research XIX (1): 108-129.

McMichael, Phillip. 2012. Development and Social Change: A Global Perspective. 5th ed. Thousand Oaks, CA: Sage.

Ohmae, Kenichi. 1990. Beyond National Borders: Reflections on Japan and the World. Homewood, IL: Dow Jones-Irwin. . 1995. "Putting Global Logic First." Pp. 129-140 in The Evolving Global Economy: Making Sense of the New World Order edited by Kenichi Ohmae. Cambridge: Harvard Business Review Book.

Peck J. 2001. "Neoliberalizing States." Progress in Human Geography 25(3):445-455

Peck J. and Tickell A. 2002. "Neoliberalizing Space." Antipode 34(3):380-404.

Sassen, Saskia. 2013. "Expelled: Humans in Capitalism's Deepening Crisis." JWSR 19(2)

Scoones, Ian. 2008. "Mobilizing against GM Crops in India, South Africa, and Brazil." Pp. 147-176 in Transnational agrarian Movements: Confronting Globalization edited by Sauenino M. Borras Jr, Marc Edelman, and Cristóbal Kay. Oxford: Blackwell Publishing.

Sklair, Leslie. 1999. "Competing Conceptions of Globalization." Journal of World Systems Research 2: 143-163.

Smith, Jackie and Dawn Wiest. 2012. Social Movements in the World-System. New York: Russell Sage Foundation.

Strange, Susan. 1996. The Retreat of the State: The Diffusion of Power in the World Economy. Cambridge: Cambridge University Press.

Subramaniam, Mangala. 2014. "Neoliberalism and Water Rights: Case of India." Current Sociology 62(3): 393-411.

1976. The Modern World-System: Capitalist Agriculture and the Origins of the European World-Economy in the Sixteenth Century. New York: Academic Press 2004. World-Systems Analysis: An Introduction. Durham, NC: Duke University Press.

Wallerstein, Immanuel and Joan Smith. 1984. "Core-periphery and Household Structures" Pp. 253-262 in Households and the World Economy edited by Joan K. Smith, Immanuel Wallerstein and Hans-Dieter Evers. Beverly Hills, CA: Sage Publications. 